\title{
PENGARUH KUALITAS LAYANAN PADA KEPUASAN DAN LOYALITAS KONSUMEN PEMBELANJAAN DARING (KETERLIBATAN PRODUK SEBAGAI PEMODERASI)
}

\author{
Cempaka Paramita \\ Universitas Gadjah Mada, Yogyakarta \\ e-mail: paramita.cempaka@gmail.com \\ Sahid Susilo Nugroho \\ Universitas Gadjah Mada, Yogyakarta \\ e-mail: sahidnugroho@ymail.com
}

\begin{abstract}
The objective of this study is to examine the effect of e-service quality that consists of six dimensions: website design, reliability, customer service, security/privacy, personalization, and enjoyment, on consumer satisfaction and loyalty in online shopping. It also seeks to verify the moderating role of product involvement in the relationship between e-service quality dimensions and consumer satisfaction. The study reached 198 respondents. Simple, multiple, and hierarchical regression analyses were employed to test the proposed hypotheses. Findings of the study indicate that reliability and security/privacy are the main predictors of consumer satisfaction, whereas website design, customer service, personalization, and enjoyment have no positive effect on consumer satisfaction. It is confirmed that consumer satisfaction has positive effect on consumer loyalty. Consumer satisfaction mediates the positive effect of reliability and security/privacy on consumer loyalty. However, product involvement has no moderating role in the relationship between e- service quality dimensions and consumer satisfaction.
\end{abstract}

Keywords: e-service quality, satisfaction, loyalty

\begin{abstract}
Abstrak
Penelitian ini menguji pengaruh kualitas layanan elektronik, yang terdiri dari dimensi desain situs, reliabilitas, layanan pelanggan, keamanan/privasi, personalisasi, dan kesenangan, pada kepuasan dan loyalitas konsumen dalam pembelanjaan online atau dalam jaringan (daring). Penelitian ini juga menguji peran moderasi dari keterlibatan produk pada hubungan antara dimensidimensi kualitas layanan elektronik dan kepuasan konsumen. Sampel penelitian berdasarkan survei daring dan non-daring terhadap 198 pembeli daring. Pengujian hipotesis menggunakan regresi sederhana, regresi berganda, dan regresi hirarkis. Hasil penelitian menunjukkan dimensi reliabilitas dan keamanan/privasi merupakan dimensi utama penentu kepuasan konsumen, sementara dimensi desain situs, layanan pelanggan, personalisasi, dan kesenangan tidak berpengaruh pada kepuasan konsumen. Penelitian ini menegaskan pengaruh positif kepuasan pada loyalitas konsumen dalam pembelanjaan daring. Kepuasan konsumen memediasi pengaruh positif dimensi reliabilitas dan keamanan/privasi dari kualitas layanan elektronik pada loyalitas konsumen. Namun, keterlibatan produk ternyata tidak memoderasi hubungan dimensi-dimensi kualitas layanan elektronik dan kepuasan konsumen.
\end{abstract}

Kata kunci: kualitas layanan elektronik, kepuasan, loyalitas

\section{PENDAHULUAN}

Kehadiran internet dan perkembangan infrastrukturnya telah memberi peluang baru bagi dunia bisnis, terutama bagi para pemasar dalam menjangkau sejumlah besar konsumen yang tersebar di berbagai lokasi geografis yang berbeda (Chen and Chang, 2003). Semakin banyak 
perusahaan memasarkan produk melalui toko atau situs belanja online atau dalam jaringan (daring) seperti Amazon.com, Walmart.com, dan Lazada.co.id dengan varian produk yang beragam yang bisa dibeli kapan saja, dimana saja. Menurut Cox and Dale (2001) serta Zeithaml et al. (2002), keberhasilan perusahaan dalam bisnis ritel daring tidak hanya ditentukan oleh kepemilikan situs dan penawaran harga yang murah, tetapi juga bagaimana memberikan layanan yang berkualitas pada konsumennya. Oleh karena itu, perlu dipahami bagaimana konsumen mempersepsikan kualitas layanan serta apa konsekuensi dari kualitas layanan tersebut yang dapat berpengaruh positif bagi perkembangan bisnis ritel daring.

Penelitian mengenai kualitas layanan dalam lingkup bisnis tradisional yang tidak berbasis internet pada umumnya mengacu pada skala SERVQUAL (service quality) yang dikembangkan oleh Parasuraman et al. (1985,
1988, 1991) yang terdiri dari 5 (lima) dimensi, yaitu: tangibles, reliabilitas, daya tanggap, jaminan, dan empati yang menekankan pentingnya interaksi langsung antara konsumen dan perwakilan perusahaan. Namun, perbedaan antara lingkungan belanja tradisional dan lingkungan belanja daring membuat skala tersebut harus diformulasi ulang (Santos, 2003; van Riel et al., 2004). Dimensi tangibles dan empati dinilai tidak tepat diterapkan dalam konteks pembelanjaan daring (Jun et al., 2004; Parasuraman and Grewal, 2000). Skala SERVQUAL tradisional juga tidak mempertimbangkan aspek keamanan, privasi, dan kemudahan dalam bertransaksi yang merupakan faktor penting dalam transaksi daring. Berbagai penelitian kemudian mengidentifikasi dan mengembangkan dimensi- dimensi dari kualitas layanan untuk lingkup bisnis daring, yang disebut juga dengan kualitas layanan elektronik, seperti yang disajikan di Tabel 1.

Tabel 1: Perkembangan Beberapa Penelitian Mengenai Dimensi Kualitas

Layanan Elektronik

\begin{tabular}{|c|c|c|c|}
\hline No. & Peneliti & Dimensi Kualitas Layanan Elektronik & Metode dan Sampel \\
\hline 1. & $\begin{array}{l}\text { Zeithaml et al., } \\
\text { (2000) }\end{array}$ & $\begin{array}{l}\text { 11 dimensi: 1) akses, 2) kemudahan navigasi, 3) efisiensi, 4) } \\
\text { fleksibilitas, 5) reliabilitas, 6) customization/personalisasi, 7) } \\
\text { keamanan/privasi, 8) daya tanggap, 9) jaminan/kepercayaan, } \\
\text { 10) estetika situs, dan 11) pengetahuan tentang harga. }\end{array}$ & $\begin{array}{l}\text { Wawancara focus } \\
\text { group pada beberapa } \\
\text { konsumen daring. }\end{array}$ \\
\hline 2. & $\begin{array}{l}\text { Yoo and Donthu } \\
\text { (2001): ITEQUAL }\end{array}$ & $\begin{array}{l}4 \text { dimensi: 1) kemudahaan penggunaan, 2) desain estetika, 3) } \\
\text { kecepatan pemrosesan, dan 4) keamanan. }\end{array}$ & Survei pada mahasiswa. \\
\hline 3. & Santos (2003) & $\begin{array}{l}5 \text { dimensi inkubatif: 1) kemudahan penggunaan, 2) tampilan, } \\
\text { 3) linkage, 4) struktur dan tata letak, 5) isi, dan } 6 \text { dimensi } \\
\text { aktif: 1) reliabilitas, 2) efisiensi, 3) dukungan, 4) komunikasi, } \\
\text { 5) keamanan, 6) insentif. }\end{array}$ & $\begin{array}{l}\text { Wawancara focus group } \\
\text { pada beberapa konsumen } \\
\text { daring. }\end{array}$ \\
\hline 4. & Yang et al. (2003) & $\begin{array}{l}14 \text { dimensi: 1) daya tanggap, 2) kredibilitas, 3) kemudahan } \\
\text { penggunaan, 4) reliabilitas, 5) kenyamanan, 6) akses, 7) } \\
\text { komunikasi, 8) kompetensi, 9) courtesy, 10) personalisasi, } \\
\text { 11) perbaikan yang terus-menerus, 12) kolaborasi, } \\
\text { 13) keamanan/privasi, dan 14) estetika. }\end{array}$ & $\begin{array}{l}\text { Analisis konten pada } \\
\text { berbagai komentar yang } \\
\text { diajukan konsumen pada } \\
\text { situs ulasan konsumen } \\
\text { daring. }\end{array}$ \\
\hline 5. & $\begin{array}{l}\text { Wolfinbarger and } \\
\text { Gilly (2003): TailQ }\end{array}$ & $\begin{array}{l}4 \text { dimensi: 1) desain situs, 2) pemenuhan/reliabilitas, } \\
\text { 3) keamanan/privasi, dan 4) layanan pelanggan. }\end{array}$ & $\begin{array}{l}\text { Wawancara focus group } \\
\text { pengembangan dimensi) dan } \\
\text { survei pada pembeli daring. }\end{array}$ \\
\hline 6. & Jun et al. (2004) & $\begin{array}{l}6 \text { dimensi: 1) respon yang cepat/reliabel, 2) akses, 3) } \\
\text { kemudahan penggunaan, 4) attentiveness, 5) keamanan, dan 6) } \\
\text { kredibilitas. }\end{array}$ & $\begin{array}{l}\text { Survei pada mahasiswa } \\
\text { dan profesional. }\end{array}$ \\
\hline 7. & $\begin{array}{l}\text { Lee and Lin } \\
(2005)\end{array}$ & $\begin{array}{l}5 \text { dimensi: 1) desain situs daring, 2) reliabilitas, } \\
\text { 3) daya tanggap, 4) kepercayaan, dan 5) personalisasi. }\end{array}$ & Survei pada mahasiswa. \\
\hline 8. & $\begin{array}{l}\text { Parasuraman } \text { et al. } \\
\text { (2005):E-S-QUAL } \\
\text { dan E-RecS-QUAL }\end{array}$ & $\begin{array}{l}4 \text { dimensi E-S-QUAL: 1) efisiensi, 2) pemenuhan, } \\
\text { 3) ketersediaan sistem, 4) privasi, dan } 3 \text { dimensi } \\
\text { penilaian perbaikan kualitas layanan elektronik (E- } \\
\text { RecS-QUAL): 1) daya tanggap, 2) kompensasi, dan } \\
\text { 3) kontak. }\end{array}$ & $\begin{array}{l}\text { Survei pada pembeli } \\
\text { daring. }\end{array}$ \\
\hline 9. & $\begin{array}{l}\text { Bauer et al. (2006): } \\
\text { eTransQual }\end{array}$ & $\begin{array}{l}5 \text { dimensi: 1) fungsionalitas/desain, 2) kesenangan } \\
\text { (enjoyment), 3) proses, 4) reliabilitas, dan 5) daya tanggap. }\end{array}$ & $\begin{array}{l}\text { Survè pada pembeli } \\
\text { daring. }\end{array}$ \\
\hline 10. & $\begin{array}{l}\text { Cristobal et al. } \\
\text { (2007): PeSQ }\end{array}$ & $\begin{array}{l}4 \text { dimensi: 1) desain situs, 2) layanan pelanggan, } 3 \text { ) } \\
\text { keamanan/privasi, dan 4) manajemen pemesanan. }\end{array}$ & $\begin{array}{l}\text { Surve pada pembeli } \\
\text { daring. }\end{array}$ \\
\hline
\end{tabular}


Dari Tabel 1. bisa dilihat adanya perbedaan dalam jumlah dan jenis dimensi kualitas layanan elektronik yang muncul dalam berbagai penelitian. Zeithaml et al. (2002) menyatakan bahwa kualitas layanan elektronik merupakan konstruk yang bersifat multidimensional. Hasil tinjauan literatur berbagai penelitian mengenai kualitas layanan elektronik menunjukkan adanya kesenjangan teoritis dan empiris. Kesenjangan teoritis tersebut adalah, pertama, menurut Bauer et al. (2006), mayoritas penelitian mengenai kualitas layanan elektronik hanya fokus pada dimensi-dimensi yang mengedepankan aspek fungsional/utilitarian dalam berbelanja seperti reliabilitas, keamanan/privasi, layanan pelanggan, dan desain situs, dengan mengesampingkan aspek hedonis (yang diwakili dimensi kesenangan seperti yang diajukan oleh Bauer et al., 2006). Menurut Childers et al. (2001), ketika berbelanja secara daring maupun tradisional, konsumen tidak hanya berorientasi pada tujuan (perspektif utilitarian), tapi juga menganggap belanja sebagai kesenangan (perspektif hedonis). Namun, masih relatif sedikit area studi yang menggabungkan aspek fungsional dan hedonis dari belanja sebagai bagian dari kualitas layanan elektronik dan menguji pengaruhnya pada kepuasan dan loyalitas konsumen. Kedua, berdasarkan tinjauan literatur, masih terbatas penelitian yang menguji variabel lain yang diduga bisa memoderasi pengaruh kualitas layanan elektronik pada kepuasan konsumen, khususnya yang berhubungan dengan karakteristik individual konsumen seperti keterlibatan, sesuai yang diproposisikan oleh Ranaweera et al. (2005). Kim et al. (2009) menyatakan bahwa proses pembuatan keputusan pembelian konsumen akan berbeda-beda tergantung pada keterlibatan mereka terhadap produk yang akan dibeli.

Kesenjangan empiris penelitian mengenai kualitas layanan elektronik adalah adanya inkonsistensi hasil penelitian terdahulu mengenai dimensi mana saja dari kualitas layanan elektronik yang berpengaruh pada kepuasan konsumen dalam konteks pembelanjaan daring. Hasil penelitian Jun et al. (2004) menunjukkan bahwa dimensi keamanan dari kualitas layanan elektronik tidak berpengaruh pada kepuasan konsumen, sedangkan menurut Chang and Wang (2011), dimensi tersebut terbukti berpengaruh positif pada kepuasan konsumen. Dimensi personalisasi yang diajukan oleh Jun et al. (2004) terbukti sebagai salah satu penentu kepuasan konsumen, sedangkan hasil penelitian Lee and Lin (2005) tidak menemukan adanya hubungan antara dimensi tersebut dengan kepuasan konsumen. Studi oleh Cristobal et al. (2007) mengkonfirmasi bahwa dimensi layanan pelanggan dari kualitas layanan elektronik memiliki pengaruh yang positif pada kepuasan konsumen, sedangkan hasil studi Kassim and Abdullah (2010) menunjukkan tidak adanya pengaruh dimensi tersebut pada kepuasan konsumen. Selain itu, relatif sedikit studi yang menguji peran mediasi dari kepuasan konsumen pada hubungan antara dimensi-dimensi kualitas layanan elektronik dan loyalitas konsumen dalam konteks pembelanjaan daring.

Model penelitian ini mengacu pada model penelitian yang diajukan oleh Chang and Wang (2011) serta Ranaweera et al. (2005). Chang and Wang (2011) menguji dimensi desain situs, reliabilitas, layanan pelanggan, keamanan/privasi dari kualitas layanan elektronik pada kepuasan dan loyalitas konsumen dalam pembelanjaan daring, namun tidak menguji peran moderasi dari keterlibatan pada hubungan antara kualitas layanan elektronik dan kepuasan konsumen sesuai model yang diajukan oleh Ranaweera et al. (2005). Chang and Wang (2005) juga tidak menyertakan dimensi personalisasi (seperti yang diajukan oleh Jun et al., 2004) dan kesenangan (seperti yang diajukan oleh Baur et al., 2006) sebagai bagian dari kualitas layanan elektronik. Sesuai saran Janda et al. (2002) dan Kim et al. (2009), jenis keterlibatan yang berpotensi sebagai pemoderasi dalam hubungan antara kualitas layanan elektronik dan kepuasan konsumen adalah keterlibatan produk dan perlu diteliti lebih lanjut.

Berdasar pada kesenjangan penelitian yang telah dipaparkan sebelumnya, dan dengan memodifikasi model penelitian Chang and Wang (2011) serta Ranaweera et al. (2005), maka penelitian ini menguji secara empiris pengaruh dari kualitas layanan elektronik (yang terdiri dari enam dimensi, yaitu: desain situs, reliabilitas, layanan pelanggan, keamanan/privasi, personalisasi, dan kesenangan) pada kepuasan dan loyalitas konsumen, serta menguji peran moderasi dari keterlibatan produk pada hubungan antara dimensi-dimensi kualitas layanan elektronik dan kepuasan konsumen dalam pembelanjaan daring. 


\section{KAJIAN PUSTAKA}

\section{Loyalitas, Kepuasan, dan Kualitas Layanan}

Loyalitas yang ditunjukkan konsumen tidak hanya terhadap merek atau produk saja, tetapi juga loyalitas terhadap toko atau perusahaan (Kotler dan Keller, 2012) yang bisa tercipta tidak hanya karena kepuasan terhadap produk, tapi juga karena kepuasan sebagai hasil pemberian kualitas layanan yang baik. Dalam lingkup bisnis daring, loyalitas atau loyalitas elektronik (e-loyalty) didefinisikan sebagai sikap menyenangkan yang ditunjukkan oleh konsumen terhadap bisnis daring yang menuntun pada perilaku pembelian berulang (Anderson and Srinivasan 2003). Dalam penelitian ini, loyalitas konsumen merupakan loyalitas terhadap toko daring dimana mereka pernah melakukan pembelian produk, dilihat dari adanya komitmen, niat untuk membeli kembali, dan word-of-mouth yang positif.

Kepuasan konsumen dalam lingkup bisnis daring atau kepuasan elektronik (esatisfaction), merupakan kepuasan (contentment) yang dirasakan konsumen berkenaan dengan pengalaman pembelian sebelumnya dengan perusahaan penyedia perdagangan elektronik (Anderson and Srinivasan, 2003). Chang and Wang (2011) mengartikan kepuasan tersebut sebagai keseluruhan perasaan positif dan negatif berkenaan dengan pengalaman pembelian dengan situs belanja daring tertentu, yang merupakan penilaian subjektif berdasarkan emosi pribadi konsumen. Dapat disimpulkan bahwa kepuasan konsumen dalam lingkup bisnis daring merupakan perasaan senang atau tidak senang konsumen terhadap kinerja produk atau kualitas layanan yang diberikan, apakah sesuai dengan yang diharapkan atau tidak, berdasarkan hasil evaluasi pasca pembelian atau setelah terjadinya transaksi. Dalam penelitian ini, kepuasan konsumen mengacu pada kepuasan terhadap toko daring berdasarkan pengalaman pembelian sebelumnya.

Dalam bisnis daring, kualitas layanan elektronik merupakan evaluasi dan penilaian keseluruhan konsumen terhadap keunggulan dan kualitas dari layanan elektronik yang ditawarkan perusahaan dalam lingkup pasar virtual (Santos, 2003), yang menunjukkan sejauh mana sebuah situs daring memfasilitasi proses pembelanjaan, pembelian, dan pengiriman produk atau jasa secara efektif dan efisien
(Zeithaml, 2002). Collier and Bienstock (2006) beropini bahwa kualitas layanan elektronik berhubungan dengan persepsi konsumen terhadap hasil dari layanan yang diberikan perusahaan berikut persepsi mereka terhadap perbaikan layanan jika terjadi masalah, yang mana konsumen tidak hanya peduli dengan interaksi dengan situs tapi juga bagaimana perusahaan memberikan layanan sesuai dengan yang diinginkan konsumen. Kualitas layanan yang diberikan oleh situs daring mencakup pengalaman selama dan setelah proses interaksi atau pembelian dengan situs atau toko daring.

\section{Pengembangan Hipotesis}

Studi ini mengembangkan 4 (empat) hipotesis yang menunjukkan hubungan antara variabelvariabel yang diteliti. Pemilihan enam dimensi kualitas layanan elektronik (desain situs, relibilitas, layanan pelanggan, keamanan/privasi, personalisasi, dan kesenangan) karena dianggap bisa menangkap aspek utilitarian dan hedonik dalam berbelanja serta menjelaskan secara keseluruhan aspek kualitas layanan dalam pembelanjaan ritel daring, baik sebelum maupun sesudah transaksi.

Desain situs toko daring menunjukkan tampilan visual, informasi, dan sisi fungsional situs (Bauer et al., 2006; Cristobal et al., 2007). Jika toko daring memiliki desain situs yang bisa memfasilitasi kenyamanan dalam berbelanja, memiliki tampilan informasi produk berikut cara pemesanan yang jelas, lengkap, dan relevan, maka konsumen akan merasa senang mengoperasikan situs toko tersebut karena desain situsnya sangat membantu kelancaran proses belanja. Hasil studi Chang and Wang (2011) serta Lee and Lin (2005) menunjukkan bahwa berbagai faktor yang berkenaan dengan desain situs berdampak pada persepsi mengenai kualitas layanan yang akhirnya akan mempengaruhi kepuasan konsumen dalam pembelanjaan daring. Oleh karena itu, dapat dihipotesiskan bahwa:

H1a: Dimensi desain situs dari kualitas layanan elektronik berpengaruh positif pada kepuasan konsumen toko daring.

Reliabilitas menunjukkan sejauh mana toko daring dapat diandalkan dalam proses pemesanan, pengiriman, dan jaminan ketersediaan produk (Parasuraman et al., 2005; 
Wolfinbarger and Gilly, 2003). Collier and Bienstock (2006) menyatakan bahwa peningkatan kepuasan konsumen dipengaruhi oleh kondisi apakah produk diterima tepat waktu sesuai dengan yang dijanjikan serta dalam kondisi yang baik sesuai dengan yang dipesan dan ditampilkan dalam situs toko daring. Penelitian Chang and Wang (2011) serta Cristobal et al. (2007) telah mengkonfirmasi bahwa kepuasan konsumen ditentukan oleh reliabilitas dari kualitas layanan elektronik yang diberikan oleh toko daring, sehingga dapat dirumuskan hipotesis sebagai berikut:

H1b: Dimensi reliabilitas dari kualitas dari kualita layanan elektronik berpengaruh positif pada kepuasan konsumen toko daring

Studi oleh Massad et al. (2006) menekankan pentingnya dukungan yang tulus dari karyawan atau perwakilan perusahaan agar proses komunikasi dengan konsumen melalui berbagai saluran layanan pelanggan seperti telepon, surat elektronik, fax, atau chat room (Yahoo Messenger, Skype), dapat berjalan baik dan efektif sebagai salah satu prediktor kepuasan konsumen dalam pembelanjaan daring. Toko daring yang merespon cepat dan benar atas pertanyaan atau keluhan konsumen akan membuat konsumen menilai bahwa toko tersebut benar-benar menanggapi dan melayani mereka dengan baik sehingga mereka akan memberikan penilaian yang positif yang menuntun pada kepuasan. Hasil studi Chang and Wang (2011) serta Wolfinbarger and Gilly (2003) membuktikan bahwa dimensi layanan pelanggan sebagai bagian dari kualitas layanan elektronik merupakan salah satu faktor penentu kepuasan konsumen, sehingga dapat dirumuskan hipotesis sebagai berikut:

H1c: Dimensi layanan pelanggan dari kualitas layanan elektronik berpengaruh positif pada kepuasan konsumen toko daring.

Keamanan dalam bertransaksi merupakan salah satu isu yang paling banyak dikeluhkan konsumen berkaitan dengan insiden kepuasan dalam bisnis daring (Massad et al., 2006). Jika konsumen mempersepsikan bahwa toko daring menjamin keamanan data personal dan informasi keuangan mereka, maka konsumen tersebut akan merasa senang dan nyaman dalam berbelanja karena hal tersebut dapat mengurangi potensi terjadinya kecurangan atau pengalaman yang tidak menyenangkan (Wagner and Rydstrom, 2001). Studi Jun et al. (2004) telah mengkonfirmasi bahwa perlindungan keamanan/privasi konsumen merupakan salah satu prediktor puas tidaknya konsumen atas kualitas layanan yang diberikan dalam pembelanjaan daring, sehingga dapat dirumuskan hipotesis berikut:

H1d: Dimensi keamanan/privasi dari kualitas layanan elektronik berpengaruh positif pada kepuasan konsumen toko daring.

Hasil studi Jun et al. (2004) menunjukkan bahwa konsumen menginginkan perhatian yang personal dan individual dari toko daring. Personalisasi layanan tersebut akan membuat konsumen merasa diperlakukan dengan baik secara individual sehingga konsumen akan menilai positif dan merasa senang dengan layanan yang diberikan oleh toko daring. Respon positif tersebut akan menuntun pada kepuasan terhadap toko daring. Hasil penelitian Jun et al. (2004) dan Kim et al. (2009) telah membuktikan bahwa dimensi personalisasi dari kualitas layanan elektronik akan mempengaruhi kepuasan terhadap toko daring dimana mereka berbelanja. Mengacu pada penjelasan tersebut, maka dapat dirumuskan hipotesis sebagai berikut:

H1e: Dimensi personalisasi dari kualitas layanan elektronik berpengaruh positif pada kepuasan konsumen toko daring.

Swinyard (1993) menyatakan bahwa lingkungan toko yang menyenangkan bisa meningkatkan keterikatan konsumen dalam aktivitas belanja. Dalam pembelanjaan daring, hal tersebut dapat diwujudkan dengan penyediaan fasilitas hiburan seperti musik, permainan, atau undian yang diharapkan bisa membuat konsumen merasa senang dan gembira ketika bertransaksi dengan toko daring tertentu (Baur et al., 2006; Elliot and Speck, 2005). Penelitian yang dilakukan oleh Carlson and O'Cass (2010) telah membuktikan bahwa salah satu sumber kepuasan konsumen dalam pembelanjaan daring adalah kesenangan yang mereka dapatkan selama proses transaksi. Berdasarkan paparan tersebut, dapat dirumuskan hipotesis sebagai berikut:

H1f: Dimensi kesenangan dari kualitas layanan elektronik berpengaruh positif pada kepuasan konsumen toko daring. 
Chang et al. (2009) berpendapat bahwa kepuasan konsumen dalam pembelanjaan daring merefleksikan kesan kumulatif konsumen terhadap kinerja toko daring yang pada akhirnya akan mempengaruhi loyalitas konsumen pada toko tersebut. Konsumen yang puas cenderung bersikap positif terhadap produk atau perusahaan, memiliki komitmen dan niat untuk membeli kembali sebagai indikasi dari loyalitas, sedangkan konsumen yang tidak puas cenderung akan mencari alternatif produk atau perusahaan lain dan menjadi lebih terbuka pada penawaran yang diajukan pesaing (Anderson and Srinivasan, 2003). Oleh karena itu, dapat dirumuskan hipotesis berikut:

H2: Kepuasan konsumen toko daring berpengaruh positif pada loyalitas konsumen toko daring.

Kualitas layanan, kepuasan, dan loyalitas merupakan konsep-konsep yang saling berkaitan satu sama lain yang mana secara teoritis berdasarkan paradigma harapan/diskonfirmasi dalam teori proses, kualitas layanan merupakan konstruk anteseden dari kepuasan, dan loyalitas merupakan hasil dari kepuasan konsumen (Caruana, 2002). Studi oleh Carlson and O'Cass (2010) juga telah mengkonfimasi bahwa kepuasan konsumen berperan sebagai pemediasi pada hubungan antara kualitas layanan dan niat konsumen untuk kembali terlibat dan merekomendasikan toko tersebut kepada pihak lain yang meminta pendapat mereka. Dimensi desain situs dari kualitas layanan elektronik merupakan salah satu penentu kepuasan konsumen dalam pembelanjaan daring, yang mana kepuasan tersebut akan menuntun pada loyalitas terhadap toko dimana konsumen melakukan pembelian produk (Chang and Wang, 2011; Cristobal et al., 2007). Hal tersebut menunjukkan bahwa loyalitas konsumen akan tercipta jika konsumen merasa senang mengoperasikan situs toko daring karena desain situsnya memiliki tampilan yang menarik, informatif, dan memiliki sistem navigasi yang baik. Berdasarkan penjelasan tersebut maka peneliti merumuskan hipotesis sebagai berikut:

H3a: Kepuasan konsumen toko daring memediasi pengaruh positif dimensi desain situs dari kualitas layanan elektronik pada loyalitas konsumen toko daring.
Hasil penelitian Chang and Wang (2011) serta Cristobal et al. (2007) menunjukkan bahwa reliabilitas sebagai bagian dari kualitas layanan elektronik merupakan prediktor kepuasan konsumen dalam pembelanjaan daring. Konsumen yang puas karena toko daring dimana mereka berbelanja mengirimkan produk tepat waktu sesuai dengan yang mereka pesan akan membuat konsumen berkomitmen untuk kembali melakukan pembelian produk di toko tersebut ataupun merekomendasikan toko tersebut ke teman, keluarga, atau orang-orang di sekitar mereka. Hal ini menunjukkan bahwa konsumen yang puas akan reliabilitas kualitas layanan dalam pembelanjaan daring akan menjadi loyal pada toko tersebut, sehingga dapat dirumuskan hipotesis:

H3b: Kepuasan konsumen toko daring memediasi pengaruh positif dimensi reliabilitas dari kualitas layanan elektronik pada loyalitas konsumen toko daring.

Kepuasan konsumen dalam pembelanjaan daring juga bisa tercipta jika konsumen merasa puas terhadap layanan pelanggan yang diberikan oleh toko daring (Chang and Wang, 2011; Wolfinbarger and Gilly, 2003). Kepuasan sebagai akibat dari kualitas layanan pelanggan yang baik tersebut akan menimbulkan niat konsumen untuk melakukan pembelian kembali atau untuk merekomendasikan toko daring ke pihak lain. Studi oleh Chang and Wang (2011) serta Cristobal et al. (2007) membuktikan bahwa layanan pelanggan merupakan penentu loyalitas konsumen sebagai akibat dari kepuasan terhadap toko daring. Oleh karena itu, dapat dirumuskan hipotesis:

H3c: Kepuasan konsumen toko daring memediasi pengaruh positif dimensi layanan pelanggan dari kualitas layanan elektronik pada loyalitas konsumen toko daring.

Keamanan/privasi telah terbukti sebagai penentu kepuasan konsumen atas kualitas layanan yang diberikan dalam pembelanjaan daring (Chang and Wang, 2011; Wolfinbarger and Gilly, 2003). Kepuasan tersebut pada akhirnya akan menimbulkan keinginan untuk melakukan pembelian kembali atau menceritakan pada pihak lain berkenaan dengan pengalaman belanja daring mereka yang memuaskan karena mereka mendapatkan 
jaminan keamanan dalam transaksi keuangan dan data-data pribadi mereka digunakan hanya untuk kepentingan transaksi. Penelitian Chang and Wang (2011) serta Cristobal et al. (2007) telah mengkonfirmasi bahwa dimensi keamanan/privasi dari kualitas layanan elektronik berpengaruh pada loyalitas konsumen jika konsumen merasa puas, sehingga dapat dihipotesiskan bahwa:

H3d: Kepuasan konsumen toko daring memediasi pengaruh positif dimensi keamanan/privasi dari kualitas layanan elektronik pada loyalitas konsumen toko daring.

Konsumen yang mendapatkan perhatian individual atau layanan yang personal seperti misalnya penyediaan alternatif sistem pembayaran atau pengiriman produk sesuai pilihan akan membuat mereka memberikan evaluasi positif pada toko daring yang menuntun pada kepuasan dan akhirnya membuat mereka berkomitmen terhadap pembelian ulang dan merekomendasikan toko daring dimana mereka pernah berbelanja ke pihak lain. Hal tersebut berarti bahwa loyalitas konsumen akan tercipta jika mereka puas atas personalisasi layanan yang diberikan toko daring, sehingga dapat dirumuskan hipotesis sebagai berikut:

H3e: Kepuasan konsumen toko daring memediasi pengaruh positif dimensi personalisasi dari kualitas layanan elektronik pada loyalitas konsumen toko daring.

Dalam pembelanjaan daring, kualitas layanan yang membuat aktivitas belanja konsumen menjadi menyenangkan akan berpengaruh pada peningkatan kepuasan konsumen (Carlson and O'Cass, 2010). Dimensi kesenangan sebagai bagian dari kualitas layanan elektronik yang diajukan oleh Bauer et al. (2006) diwujudkan dengan memasukkan unsur hiburan seperti musik atau permainan yang menurut Kim et al. (2009), hal tersebut akan menentukan apakah konsumen menilai bahwa aktivitas belanja mereka menyenangkan atau tidak. Kesenangan yang dirasakan konsumen dalam berbelanja akan mempengaruhi kepuasan mereka yang pada akhirnya membuat konsumen tersebut menjadi loyal pada toko daring (Semejin and van Riel, 2006). Berdasarkan penjelasan tersebut, maka dapat dihipotesiskan bahwa:
H3f: Kepuasan konsumen toko daring memediasi pengaruh positif dimensi kesenangan dari kualitas layanan elektronik pada loyalitas konsumen toko daring.

Dalam penelitian ini, konsep keterlibatan yang digunakan adalah keterlibatan produk. Mengacu pada Zaichowsky (1985) serta Laurent and Kapferer (1985), keterlibatan produk diartikan sebagai relevansi personal konsumen terhadap suatu produk berdasarkan kebutuhan, nilai, dan ketertarikan terhadap produk tersebut dengan mempertimbangkan kepentingan dan risiko dari pembelian produk tersebut. Konsep keterlibatan produk dalam studi ini mengadopsi CIP (Consumer Involvement Profile) yang diajukan oleh Laurent and Kapferer (1985) yang mengandung 5 (lima) komponen, yaitu: (1) ketertarikan atau kepentingan yang dipersepsikan terhadap produk berkenaan dengan arti personal dari produk tersebut, (2) makna atau nilai simbolis yang dipersepsikan dari produk berkenaan dengan apa yang dirasakan dan diharapkan terhadap produk tersebut berkaitan dengan status atau kepribadian, (3) nilai hedonis atau kesenangan yang dipersepsikan dari produk berkenaan dengan daya tarik emosional dari produk yang bisa memberikan pengaruh dan kesenangan, (4) kepentingan risiko yang dipersepsikan berkenaan dengan konsekuensi negatif yang muncul akibat dari kesalahan dalam membuat pilihan produk, dan (5) kemungkinan risiko yang dipersepsikan karena kesalahan dalam pembelian. Dengan mengaplikasikan teori Elaboration Likelihood Model (ELM) (Petty and Cacioppo, 1986 dalam Elliot and Speck, 2005) dalam konteks pembelanjaan daring, konsumen yang terlibat dengan produk yang dibeli akan terlibat dalam elaborasi yang lebih luas dan cenderung lebih memperhatikan, mengevaluasi, dan mendayagunakan informasi yang disediakan sehingga informasi tersebut akan menjadi sangat berguna dalam proses pembuatan keputusan. Hal tersebut akan menuntun pada meningkatnya persepsi konsumen terhadap kualitas layanan dari toko daring yang akhirnya mempengaruhi kepuasan mereka. Di sisi lain, konsumen yang tidak begitu terlibat dengan produk yang akan dibeli maka mereka tidak begitu terlibat dalam proses evaluasi informasi dan lebih tertarik pada aspek-aspek peripheral, misalnya penyediaan 
fasilitas musik atau permainan yang memfasilitasi proses belanja, tapi bukan merupakan bagian dari penyelesaian tugas dalam berbelanja.

Keterlibatan konsumen terhadap produk akan membuat mereka menghabiskan lebih banyak waktu untuk berinteraksi dengan situs guna mencari informasi tentang produk atau tata cara pemesanan produk yang akan menentukan proses pembuatan keputusan pembelian konsumen (Kim et al., 2009). Jika konsumen memiliki penilaian yang baik karena desain situs toko mudah dioperasikan dan informatif, maka mereka akan betah berlamalama berinteraksi dengan situs, yang akhirnya akan menuntun pada peningkatan kepuasan terhadap kualitas layanan. Di sisi lain, jika konsumen menganggap bahwa produk yang dibeli tidak terlalu penting, konsumen tersebut cenderung pasif dalam pencarian informasi selama proses pembuatan keputusan pembelian, sehingga tidak akan terlalu lama berinteraksi dengan situs. Dari penjelasan tersebut, maka dapat dirumuskan hipotesis sebagai berikut:

H4a: Keterlibatan produk memoderasi hubungan dimensi desain situs dari kualitas layanan elektronik dan kepuasan konsumen toko daring.

Keterlibatan konsumen terhadap produk yang dibeli membuat mereka menuntut agar produk tersebut diterima dalam kondisi yang utuh dan baik sesuai dengan apa yang dipesan, sehingga konsumen akan mengutamakan reliabilitas dalam hal jaminan ketersediaan dan pengiriman produk sebagai bagian penting dari kualitas layanan. Jika toko daring mampu memberikan kualitas layanan yang reliabel, maka akan membuat konsumen merasa puas. Namun, jika konsumen tidak begitu terlibat dengan produk yang dibeli (misalnya menganggap bahwa produk tersebut tidak penting), keterlambatan proses pengiriman atau ketidakjelasan penawaran produk kemungkinan tidak akan terlalu dihiraukan konsumen sebagai hal yang mempengaruhi kepuasan mereka terhadap toko daring dimana mereka berbelanja, sehingga dapat dikembangkan hipotesis sebagai berikut:

H4b: Keterlibatan produk memoderasi hubungan dimensi reliabilitas dari kualitas layanan elektronik dan kepuasan konsumen toko daring.
Interaksi tidak langsung dalam pembelanjaan daring membuat toko daring menyediakan program layanan pelanggan melalui berbagai saluran komunikasi agar konsumen dapat dengan cepat dan mudah menghubungi pihak perwakilan toko daring. Berdasar pada teori ELM, keterlibatan konsumen dengan produk yang mereka beli akan membuat mereka lebih aktif dalam proses pencarian informasi yang mendukung aktivitas belanja. Konsumen akan lebih banyak bertanya (misalnya tentang atribut produk, cara pemesanan, atau pengiriman produk) sehingga mereka akan mendayagunakan berbagai saluran komunikasi yang disediakan. Jika konsumen mendapatkan respon sesuai yang diinginkan, konsumen akan memberi penilaian positif terhadap kualitas layanan pelanggan yang akhirnya menuntun pada peningkatan kepuasan. Konsumen yang menilai bahwa mereka tidak begitu mementingkan produk yang dibeli, tidak akan melakukan proses pencarian informasi yang intensif sehingga mereka tidak akan terlibat aktif dalam proses interaksi dengan toko daring. Berdasarkan paparan tersebut, maka dapat dihipotesiskan bahwa:

$\mathrm{H} 4 \mathrm{c}$ : Keterlibatan produk memoderasi hubungan dimensi layanan pelanggan dari kualitas layanan elektronik dan kepuasan konsumen toko daring.

Jaminan keamanan transaksi dan perlindungan privasi merupakan faktor penting dari kualitas layanan yang akan menuntun pada pembentukan kepuasan konsumen dalam pembelanjaan daring (Chang and Wang, 2011). Keterlibatan konsumen dengan produk yang dibeli akan membuat mereka aktif mencari informasi tidak hanya seputar produk tetapi juga bagaimana jaminan keamanan selama proses transaksi belanja berikut perlindungan terhadap data personal konsumen. Jika toko daring memiliki sistem keamanan dan proteksi privasi yang jelas, maka akan membuat konsumen merasa puas atas kualitas layanan yang diberikan, sehingga dirumuskan hipotesis: H4d: Keterlibatan produk memoderasi hubungan dimensi keamanan/privasi dari kualitas layanan elektronik dan kepuasan konsumen toko daring. 


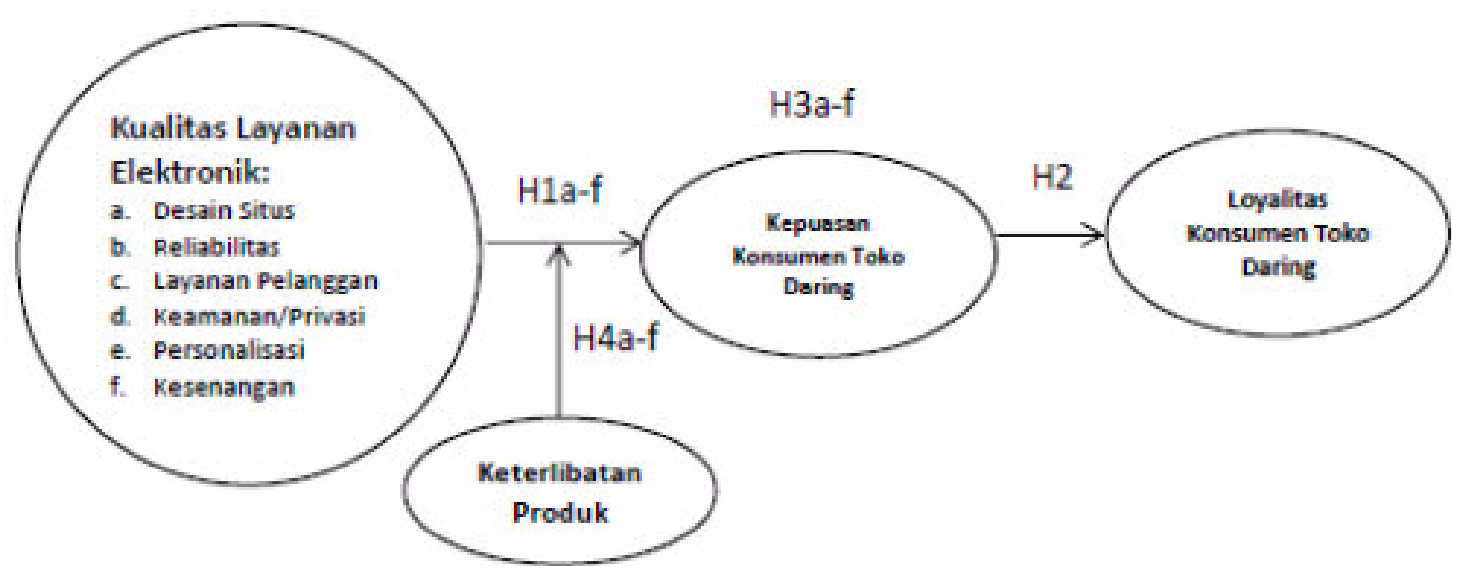

Gambar 1: Model Penelitian

Sumber: dimodifikasi dari Chang and Wang (2011) serta Ranaweera et al (2005).

Keterlibatan konsumen terhadap produk yang dibeli akan membuat konsumen lebih menginginkan untuk diperhatikan secara personal karena mereka akan lebih banyak mencari informasi tentang produk. Sebaliknya, jika konsumen tidak begitu terlibat dengan produk yang dibeli, mereka tidak akan aktif mencari informasi sehingga mereka tidak begitu menuntut adanya layanan personal dari toko daring sebagai salah satu faktor yang akan menentukan puas tidaknya mereka atas kualitas layanan yang diberikan. Berdasarkan paparan tersebut, dapat dihipotesiskan bahwa:

H4e: Keterlibatan produk memoderasi hubungan dimensi personalisasi dari kualitas layanan elektronik dan kepuasan konsumen toko daring.

Sesuai teori ELM, konsumen yang terlibat dengan produk akan dibeli biasanya akan terlibat aktif dalam proses pencarian informasi tentang produk tersebut, dan cenderung menghiraukan aspek hiburan atau fasilitas kesenangan yang disediakan. Di sisi lain, konsumen yang tidak begitu terlibat dengan produk yang akan dibeli, akan lebih mencurahkan perhatiannya pada aspek kesenangan dalam berbelanja. Fasilitas hiburan (musik, undian, atau permainan) akan membuat konsumen tersebut senang berinteraksi dengan situs selama proses belanja yang akhirnya menuntun pada kepuasan mereka terhadap kualitas layanan sehingga dapat dirumuskan hipotesis:

H4f: Keterlibatan produk memoderasi hubungan dimensi kesenangan dari kualitas layanan elektronik dan kepuasan konsumen toko daring.

\section{METODE PENELITIAN}

\section{Penyampelan dan Pengumpulan Data}

Desain pengambilan sampel penelitian ini menggunakan pendekatan non-probabilitas dengan metode penyampelan purposive judgment, yang mana peneliti menentukan kriteria sampel yang akan dijadikan responden penelitian (Cooper and Schindler, 2011). Kriteria responden adalah individu atau konsumen yang pernah melakukan pembelian produk fisik (bukan jasa) secara ritel dalam rentang waktu 1 (satu) tahun terakhir di took daring yang memiliki domain situs sendiri (misalnya Bhinneka.com atau Zalora.co.id), bukan pada situs portal, situs perantara jual beli, situs berbasis blog, atau media jejaring sosial (misalnya Olx.co.id atau Facebook.com). Pemilihan rentang waktu 1 tahun tersebut sesuai dengan penelitian yang dilakukan oleh Chang and Wang (2011), Francis (2007), dan Jun et al. (2004), serta berdasarkan pertimbangan untuk mengurangi kesalahan karena memori (efek mengingat kembali) sehingga responden masih mampu mengingat pengalaman belanja mereka sebelumnya. Peneliti membatasi jenis produk yang dibeli pada produk dengan kategori barang (produk fisik), bukan jasa (misalnya produk wisata atau jasa keuangan karena adanya perbedaan karakteristik antara barang dan jasa dikhawatirkan akan menimbulkan perbedaan dalam kualitas layanan yang diberikan.

Pengumpulan data dilakukan dengan mendistribusikan kuesioner melalui survei baik secara daring (mengirimkan alamat link/tautan kuesioner ke responden untuk diisi secara 
daring) maupun non-daring (mendatangi responden secara langsung untuk mengisi kuesioner secara tertulis/manual). Penggabungan antara survei daring dan non-daring tersebut dengan tujuan untuk mendapatkan tingkat respon yang tinggi. Tidak terdapat perbedaan hasil dari dua jenis survei tersebut karena jenis dan jumlah pernyataan yang diajukan dalam kuesioner semuanya sama. Kuesioner yang didistribusikan dalam penelitian ini berjumlah 319 dalam rentang waktu kurang lebih 2,5 bulan mulai dari pertengahan Juni sampai dengan akhir Agustus 2013 ke berbagai propinsi di Indonesia. Kuesioner yang kembali berjumlah 266 atau dengan tingkat respon sebesar $84,01 \%$. Sebanyak 68 kuesioner tidak dapat digunakan karena pengisian data yang tidak lengkap atau tidak sesuai dengan objek penelitian dilihat dari jenis produk yang dibeli dan toko daring tempat membeli produk tersebut. Dari hasil pendistribusian kuesioner tersebut, ukuran sampel yang dapat digunakan adalah 198 responden.

Dilihat dari lokasi domisili, mayoritas responden berasal dari Pulau Jawa $(65,7 \%)$. Sebagian besar responden $(53,5 \%)$ telah menggunakan internet selama lebih dari 5-10 tahun. Mayoritas responden $(60,6 \%)$ didominasi oleh wanita. Sebagian besar responden $(49,5 \%)$ berada dalam rentang usia 26-35 tahun. Tingkat pendidikan terakhir mayoritas responden adalah S1 $(74,2 \%)$. Kebanyakan responden $(41,4 \%)$ berprofesi sebagai mahasiswa. Dilihat dari usia dan latar belakang pendidikan, mayoritas responden berasal dari kaum muda dengan rentang usia 16-35 tahun dan berlatar belakang pendidikan sarjana strata 1 . Hal tersebut sesuai dengan hasil penelitian Swinyard and Smith (2003) serta Chang and Wang (2011) yang menyatakan bahwa mayoritas pembeli daring melalui internet adalah mereka yang berusia muda dan memiliki latar belakang pendidikan yang baik. Berkenaan dengan pembelanjaan daring, mayoritas responden $(42,9 \%)$ melakukan pembelanjaan sebanyak 2-3 kali dalam setahun. Produk yang paling sering dibeli adalah produkproduk fesyen seperti pakaian, tas, sepatu, dan aksesoris, dengan proporsi 53,0 \%. Sebagian besar responden $(55,6 \%)$ melakukan pembelian di berbagai toko daring dan sisanya, yakni 44,4 $\%$, berbelanja di toko daring yang cukup terkenal seperti Bhinneka.com, Amazon.com, dan Zalora.co.id. Mayoritas responden $(57,1 \%)$ telah berbelanja di toko-toko daring tersebut sebanyak 2-4 kali.

\section{Pengukuran Variabel}

Pengukuran variabel-variabel dalam penelitian ini bersumber dari beberapa penelitian terdahulu yang dimodifikasi sesuai dengan konteks penelitian (lihat Lampiran 1). Skala pengukuran yang digunakan untuk mengukur seluruh variable dalam penelitian ini adalah Skala Likert berupa 5 skala interval dimulai dari 1 yang mewakili penilaian "sangat tidak setuju", selanjutnya 2 yang mewakili penilaian "tidak setuju", kemudian 3 yang berarti "netral", 4 yang berarti "setuju", dan 5 yang berarti "sangat setuju".

\section{Teknik Analisis Data}

Analisis data dilakukan secara kuantitatif berdasarkan hasil jawaban responden pada butirbutir pernyataan dalam kuesioner. Analisis data dalam penelitian ini dilakukan menggunakan analisis regresi berganda untuk pengujian hipotesis 1a-1f, analisis regresi sederhana untuk pengujian hipotesis 2 , serta analisis regresi hirarkis untuk pengujian hipotesis 3a-3f (uji mediasi) dan hipotesis 4a-4f (uji moderasi). Analisis data tersebut dilakukan dengan bantuan program IBM Statistical Package for the Social Science (SPSS) versi 19.

\section{HASIL ANALISIS}

\section{Uji Validitas dan Reliabilitas}

Berdasarkan hasil uji validitas konvergen (menggunakan metode analisis faktor konfirmatori dengan batasan nilai minimum factor loading 0,45) dan uji reliabilitas (berdasarkan nilai minimum Cronbach's Alpha 0,6), dari 51 butir pengukuran yang diajukan, hanya 35 butir pernnyataan yang terbukti valid dan reliabel. Ke-35 butir pernyataan yang valid tersebut memiliki nilai factor loading 0,463-0,853 dan nilai Cronbach's Alpha 0,685-0,901. Hasil uji validitas dan reliabilitas disajikan di Tabel 2.

\section{Uji Ketepatan Model}

Hubungan antara dimensi-dimensi kualitas layanan elektronik dan kepuasan konsumen toko daring (hipotesis 1a-1f) dievaluasi dengan model regresi pertama yakni model regresi 
berganda seperti yang ditampilkan pada Tabel dilihat dari nilai adjusted $\mathrm{R}^{2}$, nilai $\mathrm{F}$, dan nilai $\mathrm{t}$.

3. Tingkat ketepatan model (goodness of fit)

Tabel 2: Hasil Uji Validitas dan Uji Reliabilitas

\begin{tabular}{|c|c|c|}
\hline Item & Factor Loading & Cronbach's Alpha \\
\hline Kualitas Layanan-Desain Situs 1 & 0,853 & \multirow{3}{*}{0,685} \\
\hline Kualitas Layanan-Desain Situs2 & 0,809 & \\
\hline Kualitas Layanan-Desain Situs3 & 0,522 & \\
\hline Kualitas Layanan-Reliabilitas2 & 0,690 & \multirow{4}{*}{0,727} \\
\hline Kualitas Layanan-Reliabilitas 3 & 0,771 & \\
\hline Kualitas Layanan-Reliabilitas 4 & 0,646 & \\
\hline Knalitas Layanan-Reliabilitas 5 & 0,562 & \\
\hline Kualitas Layanan-Layanan Pelanggan1 & 0,840 & \multirow{3}{*}{0,757} \\
\hline Kualitas Layanan-Layanan Pelanggan2 & 0,668 & \\
\hline Knalitas Layanan-Layanan Pelanggan 3 & 0,673 & \\
\hline Kualitas Layanan-Reamanan/Privasil & 0,463 & \multirow{5}{*}{0,870} \\
\hline Kualitas Layanan-Reamanan/Privasi2 & 0,690 & \\
\hline Kualitas Layanan-Reamanan/Privasi3 & 0,772 & \\
\hline Kualitas Layanan-Reamanan/Privasi4 & 0,835 & \\
\hline Kualitas Layanan-Keamanan/Privasi5 & 0,823 & \\
\hline Kualitas Layanas-Personalisasi2 & 0,536 & \multirow{4}{*}{0,719} \\
\hline Kualitas Layanan-Personalisasi 3 & 0,745 & \\
\hline Kualitas Layanan-Personalisasi4 & 0,698 & \\
\hline Kualitas Layanan-Personalisasis & 0,602 & \\
\hline Kualitas Layanan-Kesenangan3 & 0,820 & \multirow{3}{*}{0,738} \\
\hline Kualitas Layanan-Keseoangan4 & 0,766 & \\
\hline Kualitas Layanan-Kesenangan5 & 0,692 & \\
\hline Reterlibatan Produk3 & 0,655 & \multirow{4}{*}{0,818} \\
\hline Reterlibatan Produlk4 & 0,765 & \\
\hline Reterlibatan Produk5 & 0,832 & \\
\hline Keterlibatan Produlk6 & 0,769 & \\
\hline Kepuasan Konsumen3 & 0,724 & \multirow{4}{*}{0,823} \\
\hline Kepuasan Konsumea4 & 0,809 & \\
\hline Kepuasan Konsumen 5 & 0,539 & \\
\hline Kepuasan Konsumen6 & 0,755 & \\
\hline Loyalitas Konsumenl & 0,785 & \multirow{5}{*}{0,901} \\
\hline Loyalitas Konsumen2 & 0,781 & \\
\hline Loyalitas Konsumen3 & 0,794 & \\
\hline Loyalitas Konsumen4 & 0,700 & \\
\hline Loyalitas Konsumen 5 & 0,686 & \\
\hline
\end{tabular}

Tabel 3: Ketepatan Model Regresi Pertama (Hipotesis 1a-1f)

\begin{tabular}{lccc}
\hline \multirow{2}{*}{ Variabel Independen } & \multicolumn{3}{c}{ Variabel Dependen: Kepuasan Konsumen } \\
\cline { 2 - 4 } & $\boldsymbol{\beta}$ & $\mathbf{t}$ & Sig. \\
\hline Kualitas Layanan-Desain Situs & $-0,022$ & $-0,319$ & 0,750 \\
Kualitas Layanan-Reliabilitas & $\mathbf{0 , 2 4 5}$ & $\mathbf{3 , 3 2 4}$ & $\mathbf{0 , 0 0 1 *}$ \\
Kualitas Layanan-Layanan Pelanggan & 0,106 & 1,368 & 0,173 \\
Kualitas Layanan-Keamanan/Privasi & $\mathbf{0 , 2 2 4}$ & $\mathbf{2 , 8 1 1}$ & $\mathbf{0 , 0 0 5 *}$ \\
Kualitas Layanan-Personalisasi & 0,104 & 1,289 & 0,199 \\
Kualitas Layanan-Kesenangan & $-0,071$ & $-1,029$ & 0,305 \\
\multicolumn{1}{c}{ Adjusted $\mathbf{R}^{\mathbf{2}}$} & & 0,247 & \\
\multicolumn{1}{c}{$\mathbf{F}$} & $10,453(0,000)^{* *}$ & 0,224 & \\
\hline
\end{tabular}

**Sig. $p<0,01, *$ Sig. $p<0,05$ 
Tabel 4: Ketepatan Model Regresi Kedua (Hipotesis 2)

\begin{tabular}{cccc}
\hline \multirow{2}{*}{ Variabel Independen } & Variabel Dependen: Loyalitas Konsumen & \\
& $\boldsymbol{\beta}$ & $\mathbf{t}$ & Sig. \\
\hline Kepuasan Konsumen & $\mathbf{0 , 6 0 1}$ & $\mathbf{1 0 , 5 3 6}$ & $\mathbf{0 , 0 0 0 *}$ \\
$\mathbf{R}^{2}$ & & 0,362 & \\
Adjusted $\mathbf{R}^{\mathbf{2}}$ & & 0,358 & \\
\hline
\end{tabular}

Dari Tabel 4. diketahui bahwa model regresi pertama memiliki nilai adjusted $\mathrm{R}^{2}$ sebesar 0,224 dan nilai $\mathrm{F}$ sebesar $10,453(p<0,01)$. Dari 6 variabel independen, ternyata hanya 2 variabel (dimensi reliabilitas dan keamanan/privasi) yang memiliki pengaruh signifikan pada variabel dependen $(p<0,05)$, sedangkan 4 dimensi lainnya (desain situs, layanan pelanggan, personalisasi, dan kesenangan) tidak memiliki pengaruh yang signifikan $(p>0,05)$. Dengan demikian dapat disimpulkan bahwa model regresi tersebut memiliki ketepatan model yang kurang baik, karena 4 dari 6 variabel independen tidak memiliki pengaruh yang signifikan pada variabel dependen.

Hubungan antara kepuasan dan loyalitas konsumen toko daring (hipotesis 2) dievaluasi dengan model regresi kedua menggunakan analisis regresi sederhana seperti yang ditampilkan pada Tabel 4. Tingkat ketepatan model dilihat dari adjusted $\mathrm{R}^{2}$ memiliki nilai 0,358 dan nilai $\mathrm{t}=10,536(p<$ $0,05)$. Berdasarkan hasil regresi tersebut diketahui bahwa variabel independen berpengaruh signifikan pada variabel dependen sehingga dapat dikatakan bahwa model regresi kedua memiliki nilai ketepatan model yang cukup baik.

\section{Hasil Pengujian Hipotesis}

Hipotesis 1a-1f dalam penelitian ini diuji berdasarkan model regresi berganda. Seperti yang telah ditampilkan pada Tabel 3, dimensi reliabilitas $(\beta=0,245$, Sig. $=0,001)$ dan keamanan $/$ privasi $(\beta=0,224$, Sig. $=0,005)$ dari kualitas layanan elektronik terbukti berpengaruh positif dan signifikan $(p<0,05)$ pada kepuasan konsumen toko daring, sedangkan dimensi desain situs $(\beta=-0,022$, Sig. $=0,750)$, layanan pelanggan $(\beta=0,106$, Sig. $=0,173)$, personalisasi $(\beta=0,104$, Sig. $=0,199)$, dan kesenangan $(\beta=-0,701$, Sig. $=0,305)$ ternyata tidak berpengaruh signifikan $(p<0,05)$ pada kepuasan konsumen toko daring. Hasil tersebut menunjukkan bahwa hipotesis $1 \mathrm{~b}$ dan $1 \mathrm{~d}$ terdukung, sementara hipotesis 1a, 1c, 1e, dan 1f tidak terdukung.

Hipotesis 2 dalam penelitian ini diuji berdasarkan model regresi kedua (regresi sederhana). Hasil pengujian hipotesis seperti yang dapat dilihat pada Tabel 4. menunjukkan bahwa kepuasan konsumen toko daring berpengaruh positif dan signifikan pada loyalitas konsumen toko daring $(\beta=0,601$, Sig. $=0,000$; $p<0,05)$ yang berarti bahwa hipotesis 2 dalam penelitian ini terdukung. Hipotesis 3a-3f dalam penelitian diuji menggunakan regresi hirarkis untuk menguji peran mediasi kepuasan konsumen pada pengaruh positif dari dimensidimensi kualitas layanan elektronik pada loyalitas konsumen toko daring. Mengacu pada Baron dan Kenny (1986), analisis regresi untuk hipotesis tersebut terdiri dari 3 tahapan regresi, yaitu: (1) menguji pengaruh keenam dimensi kualitas layanan elektronik pada kepuasan konsumen, (2) menguji pengaruh keenam dimensi kualitas layanan elektronik pada loyalitas konsumen tanpa mediasi dari kepuasan konsumen, dan (3) menguji pengaruh keenam dimensi kualitas layanan elektronik pada loyalitas konsumen dengan dimasukkannnya kepuasan konsumen sebagai pemediasi. Hasil pengujian hipotesis 3a-3f tersebut dapat dilihat pada Tabel 5.

Dari Tabel 5. diketahui bahwa kepuasan konsumen toko daring terbukti memediasi pengaruh positif dimensi reliabilitas $(\beta=0,245$, Sig. $=0,001$ pada tahapan regresi 1 , $\beta=0,157$, Sig. $=0,026$ pada tahapan regresi 2 , dan $\beta=0,045$, Sig. $=0,482 ; \beta=0,458$, Sig. $=$ 0,000 pada tahapan regresi 3) dan keamanan/privasi $(\beta=0,224$, Sig. $=0,005$ pada tahapan regresi $1, \beta=0,217$, Sig. $=0,005$ pada tahapan regresi 2 , dan $\beta=0,115$, Sig. $=0,094$; $\beta=0,458$, Sig. $=0,000$ pada tahapan regresi 3) dari kualitas layanan elektronik pada loyalitas konsumen toko daring $(p<0,05)$. Namun, kepuasan konsumen tidak terbukti memediasi pengaruh positif dimensi desain situs $(\beta=$ 0,022 , Sig. $=0,750$ pada tahapan regresi $1, \beta=$ 0,076 , Sig. $=0,255$ pada tahapan regresi 2 , dan 
$\beta=0,086$, Sig. $=0,142 ; \beta=0,458$, Sig. $=0,000$ pada tahapan regresi 3$)$, layanan pelanggan $(\beta=$ 0,106 , Sig. $=0,173$ pada tahapan regresi $1, \beta=$ 0,167 , Sig. $=0,025$ pada tahapan regresi 2 , dan $\beta=0,118$, Sig. $=0,072 ; \beta=0,458$, Sig. $=0,000$ pada tahapan regresi 3$)$, personalisasi $(\beta=$ 0,104 , Sig. $=0,199$ pada tahapan regresi $1, \beta=$ 0,102 , Sig. $=0,186$ pada tahapan regresi 2 , dan $\beta=0,054$, Sig. $=0,425 ; \beta=0,458$, Sig. $=0,000$ pada tahapan regresi 3), dan kesenangan $(\beta=$ 0,071 , Sig. $=0,305$ pada tahapan regresi $1, \beta=$ 0,103 , Sig. $=0,119$ pada tahapan regresi 2 , dan $\beta=0,136$, Sig. $=0,020 ; \beta=0,458$, Sig. $=0,000$ pada tahapan regresi 3) dari kualitas layanan elektronik pada loyalitas konsumen toko daring $(p>0,05)$. Hasil tersebut menunjukkan bahwa hipotesis $3 \mathrm{~b}$ dan $3 \mathrm{~d}$ terdukung, sedangkan hipotesis 3a, 3c, 3e, dan $3 \mathrm{f}$ tidak terdukung.

Hipotesis $4 \mathrm{a}-4 \mathrm{f}$ dalam penelitian diuji menggunakan regresi hirarkis, yaitu untuk menguji peran moderasi dari keterlibatan produk pada hubungan dimensi-dimensi kualitas layanan elektronik dan kepuasan konsumen toko daring. Mengacu pada Baron dan Kenny (1986), analisis regresi untuk hipotesis tersebut terdiri dari 3 tahapan, yaitu: (1) menguji pengaruh keenam dimensi kualitas layanan elektronik pada kepuasan konsumen, (2) menguji pengaruh keenam dimensi kualitas layanan elektronik dan keterlibatan produk pada kepuasan konsumen, (3) menguji pengaruh keenam dimensi kualitas layanan elektronik, keterlibatan produk, serta interaksi antara keenam dimensi kualitas layanan elektronik dan keterlibatan produk pada kepuasan konsumen.

Efek moderasi dapat dilihat dari peningkatan nilai adjusted $\mathrm{R}^{2}$ pada ketiga tahapan regresi (Anderson, 1986). Dari tabel hasil pengujian hipotesis $4 \mathrm{a}-4 \mathrm{f}$ diketahui bahwa terdapat peningkatan nilai adjusted $\mathrm{R}^{2}\left(\square \mathrm{R}^{2}\right)$, namun hanya untuk hipotesis $4 \mathrm{~b}$ dan 4f. Dilihat dari interaksi antara variabel independen yaitu keenam dimensi kualitas layanan elektronik dan variabel pemoderasi keterlibatan produk, diketahui bahwa keterlibatan produk tidak memoderasi hubungan antara dimensi desain situs $(\beta=0,248$, Sig. $=0,695)$, reliabilitas $(\beta=-0,886$, Sig. $=0,138)$, layanan pelanggan $(\beta=0,395$, Sig. $=0,486)$, keamanan/privasi $(\beta=-0,048$, Sig. $=0,934)$, personalisasi $(\beta=-$ $0,432$, Sig. $=0,331)$, kesenangan $(\beta=0,515$, Sig. $=0,260)$ dari kualitas layanan elektronik dan kepuasan konsumen toko daring $(p<0,05)$. Berdasarkan hasil tersebut maka dapat disimpulkan bahwa hipotesis 4a-4f dalam penelitian ini tidak terdukung.

Tabel 5: Hasil Regresi untuk Pengujian Hipotesis 3a-3f

\begin{tabular}{|c|c|c|c|c|c|c|c|c|c|}
\hline \multirow{3}{*}{ Variabel Independen } & \multicolumn{3}{|c|}{ Tahap Regresi 1} & \multicolumn{3}{|c|}{$\begin{array}{c}\text { Tahap Regresi } 2 \\
\text { (tanpa variabel mediasi) }\end{array}$} & \multicolumn{3}{|c|}{$\begin{array}{c}\text { Tahap Regresi } 3 \\
\text { (dengan variabel mediasi) }\end{array}$} \\
\hline & \multicolumn{3}{|c|}{$\begin{array}{c}\text { Variabel Mediasi: } \\
\text { Kepuasan Konsumen }\end{array}$} & \multicolumn{3}{|c|}{$\begin{array}{l}\text { Variabel Dependen: } \\
\text { Loyalitas Konsumen }\end{array}$} & \multicolumn{3}{|c|}{$\begin{array}{l}\text { Variabel Dependen: } \\
\text { Loyalitas Konsumen }\end{array}$} \\
\hline & $\beta$ & $\mathrm{t}$ & Sig. & $\beta$ & $\mathrm{T}$ & Sig. & $\beta$ & $\mathrm{t}$ & Sig. \\
\hline $\begin{array}{l}\text { Kualitas Layanan- } \\
\text { Desain Situs }\end{array}$ & $-0,022$ & $-0,319$ & 0,750 & 0,076 & 1,143 & 0,255 & 0,086 & 1,474 & 0,142 \\
\hline $\begin{array}{l}\text { Kualitas Layanan- } \\
\text { Reliabilitas }\end{array}$ & 0,245 & 3,324 & $0,001 *$ & 0,157 & 2,236 & $0,026^{*}$ & 0,045 & 0,705 & 0,482 \\
\hline $\begin{array}{l}\text { Kualitas Layanan- } \\
\text { Layanan Pelanggan }\end{array}$ & 0,106 & 1,368 & 0,173 & 0,167 & 2,254 & 0,025 & 0,118 & 1,807 & 0,072 \\
\hline $\begin{array}{l}\text { Kualitas Layanan- } \\
\text { Keamanan/Privasi }\end{array}$ & 0,224 & 2,811 & $0,005^{*}$ & 0,217 & 2,861 & $0,005^{*}$ & 0,115 & 1,682 & 0,094 \\
\hline $\begin{array}{l}\text { Kualitas Layanan- } \\
\text { Personalisasi }\end{array}$ & 0,104 & 1,289 & 0,199 & 0,102 & 1,327 & 0,186 & 0,054 & 0,800 & 0,425 \\
\hline $\begin{array}{l}\text { Kualitas Layanan- } \\
\text { Kesenangan }\end{array}$ & $-0,071$ & $-1,029$ & 0,305 & 0,103 & 1,564 & 0,119 & 0,136 & 2,337 & 0,020 \\
\hline Kepuasan Konsumen & & & & & & & 0,458 & 7,565 & $0,000^{*}$ \\
\hline Adjusted $\mathrm{R}^{2}$ & & 0,224 & & & 0,295 & & & 0,456 & \\
\hline
\end{tabular}

\footnotetext{
*Sig. $p<0,05$
} 


\section{PEMBAHASAN}

Hasil pengujian hipotesis $1 \mathrm{~b}$ dan $1 \mathrm{~d}$ menunjukkan pentingnya reliabilitas dan keamanan/privasi sebagai bagian dari kualitas layanan elektronik. Hasil pengujian hipotesis 2 semakin menegaskan peran kepuasan sebagai anteseden utama loyalitas konsumen. Hasil pengujian hipotesis $3 \mathrm{~b}$ dan $3 \mathrm{~d}$ menunjukkan bahwa konsumen yang puas karena menilai bahwa toko daring memiliki jaminan ketersediaan produk, mengirim produk tepat waktu, dan dalam kondisi yang baik sesuai dengan yang dijanjikan, serta memberikan jaminan perlindungan transaksi keuangan dan proteksi terhadap data pribadi maupun aktivitas belanja konsumen akan membuat konsumen menjadi loyal terhadap toko tersebut.

Berbeda dengan hasil studi Chang and Wang (2011), hasil pengujian hipotesis 1a menunjukkan bahwa dimensi desain situs tidak terbukti sebagai prediktor kepuasan konsumen. Hal tersebut bisa dikarenakan responden beropini bahwa desain situs bukan menjadi pertimbangan utama untuk terlibat dalam pembelanjaan daring yang akan menentukan kepuasan terhadap kualitas layanan. Kemungkinan lainnya diduga karena kualitas desain situs lebih diutamakan untuk menarik konsumen baru atau dengan kata lain desain situs lebih berpengaruh pada niat beli dibandingkan pada kepuasan konsumen. Konsumen yang belum pernah melakukan pembelian produk secara daring akan sangat mengutamakan kelancaran proses awal transaksi mereka. Untuk pembelian selanjutnya, pengalaman mengoperasikan situs membuat konsumen cenderung tidak menemui kesulitan dalam menggunakan situs mulai dari mencari informasi hingga tahap pemesanan produk karena telah terbiasa dengan sistem pembelanjaan daring (Schaupp and Bèlanger, 2005). Hasil pengujian hipotesis 1c menunjukkan bahwa layanan pelanggan tidak menentukan kepuasan konsumen. Hasil tersebut berbeda dengan temuan Chang and Wang (2011), namun senada dengan hasil studi Lee and Joshi (2007) yang mana peneliti menduga bahwa layanan pelanggan melalui penyediaan berbagai saluran komunikasi oleh toko daring hanya dimanfaatkan konsumen jika menghadapi masalah dalam proses belanja misalnya kesalahan dalam pengiriman barang atau masalah proses pembayaran.
Selama proses belanja berjalan lancar, konsumen cenderung pasif dalam proses komunikasi dengan toko daring.

Berdasarkan pengujian hipotesis 1e, temuan studi menunjukkan bahwa dimensi personalisasi tidak menentukan kepuasan konsumen. Temuan tersebut sesuai dengan hasil studi Awad and Khrisnan (2006) yang menunjukkan adanya paradoks berkenaan dengan peningkatan kepedulian konsumen dalam pembelanjaan daring yang mana konsumen menginginkan transparansi informasi namun tidak begitu menginginkan untuk mendapatkan layanan yang personal karena dianggap mengganggu privasi mereka. Hasil pengujian hipotesis if menunjukkan bahwa penyediaan fasilitas hiburan (musik, undian, atau permainan) ternyata tidak berpengaruh pada kepuasan konsumen. Hasil tersebut sesuai dengan penelitian Kim et al. (2009) yang mengungkapkan bahwa konsumen tidak begitu mementingkan fasilitas hiburan yang diberikan oleh toko daring karena menganggap bahwa fasilitas tersebut justru mengganggu proses belanja mereka. Temuan studi ini juga membuktikan bahwa meskipun beberapa studi mengemukakan adanya motivasi hedonis konsumen ketika berbelanja secara daring, (misalnya Bauer et al., 2006 atau Childers et al., 2001), mayoritas pembeli daring tetaplah merupakan pembeli dengan motivasi belanja utilitarian (seperti yang dikemukakan oleh Parasuraman et al., 2005 serta Bhatnagar and Ghose, 2004), yang sangat mengutamakan efisiensi waktu, kenyamanan, dan kemudahan akses dalam berbelanja (Wolfinbarger and Gilly, 2003).

Hasil pengujian hipotesis 3a, 3c, 3e, dan $3 \mathrm{f}$ dalam penelitian ini menunjukkan bahwa kepuasan konsumen tidak memediasi pengaruh positif dimensi desain situs, layanan pelanggan, personalisasi, dan kesenangan dari kualitas layanan elektronik pada loyalitas konsumen toko daring. Senada dengan hasil hipotesis 1a, 1c, 1e, dan 1f, yang mana keempat dimensi tersebut tidak berpengaruh pada kepuasan konsumen, sehingga kepuasan konsumen tidak berperan memediasi pengaruh dari dimensi-dimensi tersebut pada loyalitas konsumen dalam pembelanjaan daring.

Berbeda dengan yang diproposisikan Ranaweera et al. (2005), hasil studi ini menunjukkan bahwa ternyata keterlibatan 
produk tidak memoderasi hubungan dimensidimensi kualitas layanan elektronik dan kepuasan konsumen toko daring. Peneliti menduga bahwa perbedaan karakteristik lingkungan belanja daring dan tradisional bisa mempengaruhi keterlibatan konsumen dengan produk yang mereka beli. Ketika berbelanja secara tradisional, kesempatan untuk menilai langsung atau berinteraksi secara fisik dengan produk maupun penjual kemungkinan akan membuat konsumen lebih terlibat dalam proses pencarian informasi tentang produk sebelum memutuskan untuk membeli. Proses penentuan kualitas produk akan lebih mudah dilakukan secara tradisional dibandingkan dengan berbelanja secara daring, sehingga ketika melakukan pembelanjaan daring, diduga bahwa konsumen tidak begitu mementingkan terlibat atau tidak terlibatnya mereka terhadap produk yang akan mereka beli di toko daring.

\section{Implikasi Penelitian}

Penelitian ini mengkonfirmasi pengaruh signifikan dimensi reliabilitas dan keamanan/privasi dari kualitas layanan elektronik pada kepuasan konsumen toko daring, sesuai dengan yang dikemukakan pada beberapa penelitian sebelumnya seperti Chang and Wang (2011) serta Cristobal et al. (2007). Kepuasan konsumen terbukti memediasi hubungan antara kualitas layanan elektronik dan loyalitas konsumen. Hasil penelitian diharapkan dapat memberikan tambahan informasi atau referensi bagi pengembangan literatur mengenai kualitas layanan dalam pembelanjaan daring.

Hasil penelitian ini diharapkan dapat memberikan beberapa masukan bagi para praktisi bisnis daring, khususnya para manajer dan pemilik toko daring atau bagi mereka yang berniat untuk membuka toko daring. Mereka harus memberikan kualitas layanan yang terbaik pada konsumen dengan fokus utama pada reliabilitas yaitu perbaikan dan peningkatan sistem manajemen pesanan, ketersediaan, dan pengiriman produk serta peningkatan jaminan keamanan dan perlindungan terhadap privasi konsumen. Senada dengan yang dikemukakan oleh Jedd (2000), toko daring harus memiliki sistem kolaborasi yang baik dalam manajemen internal mereka maupun dengan pihak eksternalnya (misalnya pemasok, perusahaan ekspedisi, atau lembaga finansial yang terlibat dalam proses pembelanjaan daring) untuk memastikan kelancaran proses pemesanan dan pengiriman produk agar tercipta kepuasan dan loyalitas konsumen. Toko daring juga harus menciptakan lingkungan belanja yang aman misalnya bekerja sama dengan lembaga keuangan yang terpercaya (proteksi terhadap data finansial konsumen) dan menggunakan data-data pribadi konsumen hanya terbatas pada penyelesaian proses belanja saja.

\section{PENUTUP}

Responden penelitian ini hanya berasal dari 1 (satu) negara. Perbedaan kultur, tingkat penerapan teknologi, akses internet, ataupun kondisi sosial ekonomi yang berbeda-beda dari tiap negara bisa menyebabkan pola perilaku konsumen daring yang berbeda pula. Penelitian ini hanya menjelaskan perilaku pembelanjaan daring yang bersifat general dan dilakukan pada satu titik waktu saja. Perilaku konsumen daring yang beragam dilihat dari jenis produk yang dibeli atau dari toko daring tempat mereka berbelanja, misalnya belanja pada produk barang atau jasa, bisa dipertimbangkan sebagai fokus penelitian selanjutnya. Faktor budaya, teknologi, atau isu sosial ekonomi bisa digunakan sebagai variabel tambahan guna memperkaya penelitian di masa yang akan datang. Penelitian lanjutan diharapkan dapat menggunakan ukuran sampel yang lebih besar dengan daerah jangkauan yang lebih luas dan sebaiknya dilakukan secara longitudinal agar dapat lebih sempurna dalam menangkap perubahan penilaian konsumen terhadap kualitas layanan elektronik yang berdampak pada kepuasan dan loyalitas dalam pembelanjaan daring.

\section{DAFTAR PUSTAKA}

Anderson, CH. 1986. Hierarchical moderated regression analysis: a useful tool for retail management decisions. Journal of Retailing. 62 (2). 186-203.

Anderson, RE. and SS. Srinivasan. 2003. Esatisfaction and e-loyalty: a contingency framework. Psychology \& Marketing. 20 (2). 123-138.

Awad, NF. and MS. Krishnan. 2006. The personalization privacy paradox: an 
empirical evaluation of information transparency and willingness to be profiled online for personalization. MIS Quarterly. 30 (1). 13-28.

Bauer, HH., T. Fallk and M. Hammerschmidt. 2006. eTransQual: a transaction process-based approach for capturing service quality in online shopping. Journal of Business Research. 59. 866875.

Bhatnagar, A. and S. Ghose. 2004. Segmenting consumers based on the benefits and risks of internet shopping. Journal of Business Research. 57 (12). 13521360.

Carlson, J. and A. O'Cass. 2010. Exploring the relationships between e-service quality, satisfaction, attitude and behaviours in content-driven e-service web sites. Journal of Services Marketing. 24 (2). 112-127.

Caruana, A. 2002. Service loyalty, the effects of service quality and the mediating role of customer satisfaction. European Journal of Marketing. 36 (7/8). 811828.

Chang, HH., YH. Wang and WY. Yang. 2009. The impact of e-service quality, customer satisfaction and e-loyalty in marketing: moderating effect of perceived value. Total Quality Management \& Business Excellence. 20 (4). 424-443.

Chang, HH. and HS. Wang. 2011. The moderating effect of customer perceived value on online shopping behavior. Online Information Review. 35 (3). 333-359.

Chen, SJ. and TZ. Chang. 2003). A descriptive model of online shopping process: some empirical results. International Journal of Service Industry Management. 14 (5). 556-569.

Childers, TL., CL. Carr., J. Peck. and S. Carson. 2001. Hedonic and utilitarian motivations for online retail shopping behavior. Journal of Retailing. 77 (4). 511-535.
Collier, JE. and CC. Bienstock. 2006. Measuring service quality in eretailing. Journal of Service Research. 8 (3). 260-275.

Cooper, DR. and PS. Schindler. 2011. Business Research Methods, $11^{\text {th }}$ edition, New York: McGraw-Hill Companies, Inc.

Cox, J. and BG. Dale. 2001. Service quality and e-commerce: an exploratory analysis. Managing Service Quality. 11 (2). 121-131.

Cristobal, E., C. Flavian and M. Guinalu. 2007. Perceived e-service quality (PeSQ), measurement validation and effects on consumer satisfaction and web site loyalty. Managing Service Quality. 17 (3). 317-340.

Elliot, MT. and PS. Speck. 2005. Factors that affect attitude toward a retail web site. Journal of Marketing Theory and Practice. 1 (1). 40-51.

Francis, JE. 2007. Internet retailing quality: one size does not fit at all. Managing Service Quality, 17 (3). 341-355.

Hellier, PK., GM. Geursen., RA. Carr. And JA. Rickard. 2003. Customer repurchase intention: a general structural equation model. European Journal of Marketing. 37 (11/12). 1762-1800.

Janda, S., PJ. Trocchia and KP. Gwinner. 2002. Consumer perceptions of internet retail service quality. International Journal of Service Industry Management. 13 (5). 412-431.

Jedd, M. 2000. Sizing up home delivery. Logistics Management and Distribution Report. 39(2). 51- 56.

Jun, M., Z. Yang and D. Kim. 2004. Customer's perceptions of online retailing service quality and their satisfaction. International Journal of Quality \& Reliability Management. 21 (8). 817-840.

Kapferer, JN. and G. Laurent. 1985/1986. Consumer involvement profile: a new practical approach to consumer involvement. Journal of Advertising Research. 25 (6). 48-56. 
Kassim, N. and NA. Abdullah. 2010. The effect of perceived service quality dimensions on customer satisfaction, trust, and loyalty in e-commerce setting. Asia Pacific Journal of Marketing and Logistic. 22 (30). 351-371.

Kim, J., B. Jin and JL. Swinney. 2009. The role of etail quality, e-satisfaction, and etrust in online loyalty development process. Journal of Retailing and Consumer Services. 16. 239- 247.

Kim, JH., M. Kim and J. Kandampully. 2009. Buying environment characteristics in the context of e-service. European Journal of Marketing. 43 (9/10). 11881204.

Kotler, P. and KL, Keller. 2012. Marketing Management, $14^{\text {th }}$ edition. Essex, England: Pearson Education Limited.

Laurent, G. and JN. Kapferer. 1985. Measuring consumer involvement profiles. Journal of Marketing Research. 22. 4153.

Lee, GG. and HF. Lin. 2005. Customer perceptions of e-service quality on online shopping. International Journal of Retail \& Distribution Management. 33 (2). 161-176.

Lee, K. and K. Joshi. 2007. An empirical investigation of customer satisfaction with technology mediated service encounters in the context of online shopping. Journal of Information Technology Management. 18 (2). 1837.

Massad, N., R. Heckman and K. Crowston. 2006. Customer satisfaction with electronic service encounter. International Journal of Electronic Commerce. 10 (4). 73-104.

Oliver, RL. 1980. A cognitive model of the antecedence and consequences of satisfaction decisions. Journal of Marketing Research. 17. 46-49.

Parasuraman, A. and D. Grewal. 2000. The impact of technology on the qualityvalue-loyalty chain: a research agenda. Journal of the Academy of Marketing
Science. 28(1). 168-174.

Parasuraman, A., VA. Zeithaml and LL. Berry. 1985. A conceptual model of service quality and its implications for future research. Journal of Marketing. 49 (4). $41-50$

Parasuraman, A., VA. Zeithaml and LL. Berry. 1988. SERVQUAL: a multiple-item scale for measuring consumer perceptions of service quality. Journal of Retailing. 64 (1). 12-40.

Parasuraman, A., VA. Zeithaml and LL. Berry. 1991. Refinement and reassessment of the SERVQUAL scale. Journal of Retailing. 67 (4). 420-450.

Parasuraman, A., VA. Zeithaml and A. Malhotra. 2005. A multiple-item scale for assessing electronic service quality. Journal of Service Research. 7 (10). 121.

Ranaweera, C., G. McDougall and H. Bansal. 2005. A model of online customer behavior during the initial transaction: moderating effects of customer characteristics. Marketing Theory. 5 (1). 51-74.

Santos, J. 2003. E-service quality: a model of virtual service quality dimensions. Managing Service Quality. 13 (3). 233246.

Schaupp, LC. and F. Bèlanger. 2006. A conjoint analysis of online consumer satisfaction. Journal of Electronic Commerce Research. 6 (2). 95-111.

Semeijn, J. and ACR. van Riel. 2006. Eservices and offline fulfillment: how eloyalty is created. Managing Service Quality. 15 (2). 182-194.

Swinyard, WR. 1993. The effect of mood, involvement, and quality of store experience on shopping intentions. Journal of Consumer Research. 20 (2). 271-280.

Swinyard, WR. and SM. Smith. 2003. Why people (don't) shop online: a lifestyle study of the internet consumer. Psychology \& Marketing. 20 (7). 567597. 
van Riel, ACR., J. Semeijn and P. Pauwels. 2004. Online travel service quality: the role of pre- transaction services. Total Quality Management. 15 (4). 475-493.

Wagner, J. and G. Rydstrom. 2001. Satisfaction, trust, and commitment in consumer relationship with online retailer. European Advances in Consumer Research. 5. 276-281.

Wolfinbarger, M. and M.C. Gilly. 2003. Etailq: dimensionalizing, measuring, and predicting etail quality. Journal of Retailing. 79 (3). 183-198.

Yang, Z. and M. Jun. 2002. Consumer perception of e-service quality: from internet purchaser and non-purchaser perspectives. Journal of Business Strategies. 19 (1). 19-41.

Yang, Z. and M. Jun. 2002. Consumer perception of e-service quality: from internet purchaser and non-purchaser perspectives. Journal of Business Strategies. 19 (1). 19-41.

Yang, Z., RT. Peterson and S. Cai. 2003. Service quality dimensions of internet retailing: an exploratory analysis.
Journal of Services Marketing. 17(7). 685-700.

Yoo, B. and N. Donthu. 2001. Developing a scale to measure the perceived quality of an internet shopping site (SITEQUAL). Quarterly Journal of Electronic Commerce. 2(1). 31-47.

Zaichkowsky, J. 1985. Measuring the involvement construct. Journal of Consumer Research.12 (3). 341-352.

Zeithaml, VA. 2002. Service excellence in electronic channels. Managing Service Quality. 12 (3). 135-139.

Zeithaml, VA., A. Parasuraman and A. Malhotra. 2000. A conceptual framework for understanding e-service quality: implications for future research and managerial practice. Working Paper No. 00-115. Marketing Science Institute, Cambridge, MA.

Zeithaml, VA., A. Parasuraman and A. Malhotra. 2002. Service quality delivery through web sites: a critical review of extant knowledge. Journal of the Academy of Marketing Science. 30 (4). 362-375. 